\title{
Australian Journal of \\ Crop Science \\ Phytoregulators and stem subdivision in the production of young forage palms (Opuntia ficus-indica and Nopalea cochellinifera)
}

\author{
Wellington Silva Gomes ${ }^{1}$, Samy Pimenta ${ }^{1}$, Poliana Soares da Cruz Mascarenhas ${ }^{1}$, Luciana Cardoso \\ Nogueira Londe ${ }^{1}$, Arles Matheus Pickler de Barros do Vale ${ }^{1}$, Suzane Ariadna de Souza ${ }^{1}$, Hélida Chisthine \\ de Freitas Monteiro ${ }^{1}$, Bruno Rafael Alves Rodrigues ${ }^{1}$, Luciano de Souza Vespoli ${ }^{1}$, Osmer Balam ${ }^{3}$
}

\author{
${ }^{1}$ State University of Montes Claros (UNIMONTES), Department of Agricutural Sciences, Janaúba - Minas Gerais, \\ Brazil \\ ${ }^{2}$ Agricultural Research Company of Minas Gerais (EPAMIG), Nova Porteirinha- Minas Gerais, Brazil \\ ${ }^{3}$ The College of Wooster, Department of Spanish, Wooster, Ohio, USA
}

*Corresponding author: wsgomes7@gmail.com

\begin{abstract}
The propagation of plants through stem subdivision and the incorporation of phytoregulators can be a viable and efficient technique in the large-scale production of young forage palm at a lower cost. This study was conducted in order to evaluate the influence of stem subdivision and phytoregulators on the production of young forage palms under greenhouse conditions. Three experiments (I, II and III) were performed. Experiments I and II consisted of young palm of the Miúda genotype, formed from fragmented stems submitted to solutions containing gradually increasing concentrations of benzylaminopurine $(0,0 ; 0,5 ; 1,0$ e 1,5 $\left.\mathrm{mg} . \mathrm{L}^{-1}\right)$ and kinetin $\left(0,0 ; 0,25 ; 0,5\right.$ e $\left.0,75 \mathrm{mg} . \mathrm{L}^{-1}\right)$ combined with naphthaleneacetic acid $\left(1,5 \mathrm{mg} . \mathrm{L}^{-1}\right)$. An additional control without the use of phytoregulators was also included. These treatments were distributed in a randomized block design (RBD), in a factorial scheme with the additional plot: $4 \times 4+1$. In experiment III, different sized fractions of four forage palm genotypes were tested: Gigante, Orelha de elefante, IPA Sertânia, and Miúda. For this test, the experimental design was RBD, with twelve treatments, distributed in five blocks with five plants per plot. There was no influence of phytoregulators on the characteristics evaluated in experiments I and II. Significant differences were found. However, for the variables length, width, and thickness of sprouts among treatments in experiment III. Therefore, the application of phytoregulators in young forage palms at the dosages used is not recommended. For the Gigante, Orelha de Elefante and Miúda genotypes, the fractional stem size recommended is $5 \times 3 \mathrm{~cm}$ whereas for IPA Sertânia, the size recommended is $4 \times 2 \mathrm{~cm}$.
\end{abstract}

Keywords: Auxin; Cytokinin; Cuttings; Propagation; Seedling production.

Abbreviations: NAA_Naphthaleneacetic acid, BAP_Benzylaminopurine, AL_Average length, DAP_days after planting, EPAMIG_Agricultural Research Company of Minas Gerais, AT Average thickness, GA $A_{3}$ Gibberellic acid, LMB Laboratory of Molecular Biology, AW_Average width, UNIMONTES_State University of Montes Claros.

\section{Introduction}

The Brazilian semiarid region, occupying an area of approximately one million $\mathrm{km}^{2}$, is characterized by typical environmental conditions of the Caatinga, which include prolonged periods of high temperatures and drought. (Pereira Júnior, 2007). These conditions not only hinder the production capacity of conventional forages, but they burden livestock activity in these regions.

The cultivation of perennial forage species, adapted to semiarid conditions, is an important alternative to the sustainability of local agriculture and in this case, forage palm varieties are a viable alternative to crop in these areas since they have morphophysiological traits that allow their efficient production in this environment (Lima et al., 2016; Silva et al., 2017)

Propagation via stem subdivision is a viable and efficient technique for the large-scale production of young plants at lower costs. However, it is known that young plant produced from subdivision grow less than those, which are propagated through the use of the whole stem (Cavalcante et al., 2017). In light of this, phytoregulators are used at the time of planting and subsequently applied to the fractionated stem in order to enhance plant growth. Under laboratory conditions, a number of compounds are related to cytokine and auxin activity (Krikorian, 1991; Pal, 2019; Rocha et al., 2018). It is understood that the correct balance of these growth regulators can determine the development of young plants (Rademacher, 2015).

Studies on the influence of phytoregulators on the production of forage palm seedlings have been reported for the production of seedlings in vitro and have demonstrated efficiency in plant development (Calaes et al., 2017). Despite its cost and laborious technique, research on the use of plant regulators is vital for several reasons; (i) understand its effects and benefits for the production of seedlings and the development of plants; and (ii) contribute to the subsequent 
dissemination of this technology for use in the field, making it available to producers. Considering that the subdivision of the stem and the use of phytoregulators can lead to an increase in the production of young plants, the rapid germination process of stem fragments and a reduction in the cost of production, the use of phytoregulators in agriculture deserves further research.

Given the limited knowledge about the use of phytoregulators in the greenhouse and seeking the development of simpler and cheaper techniques for seedling mass production the present study was carried out (i) to evaluate the influence of benzylaminopurine, kinetin and naphthalenacetic acid on seedling development and (ii) to examine the ideal dosage and fractional size of stem in the production of forage seedlings in a greenhouse.

\section{Results and discussion}

Experiments I and II - Influence of phytoregulators on the production of forage palm seedlings

For the variable mass of fragments, there were no significant differences between treatments in experiments I and II. This variable was considered as standard, to prove that the fragments had the same mass conditions in the tests since they were obtained through shapes with previously defined dimensions $(5 \times 3 \mathrm{~cm})$. The same size ensured that no fraction would have a higher reserve content than the others, which could interfere with our results since it is known that the mass of a stem influences the development of forage palm sprouts (Cavalcante et al., 2017).

Regarding the experimental precision based on the coefficient of variation (CV\%), and the classification proposed by Pimentel-Gomes (1987), a very high value was found for the variables $A L$ and $A W$ in experiment $I$ and $A L$ in experiment II, both at 45 DAP. The result reflects high residual influence, that is, there is a greater heterogeneity in this period. This result suggests that some fragments presented sprouted earlier than others. However, these values decreased throughout the evaluations, leading to the homogeneity of the plots and good analysis precision of the material, allowing high reliability of the obtained results, especially at 90 DAP in experiment II.

No significant differences were observed between treatments for the variables AL, AW and AT analyzed at 45, 60, 75 and 90 DAP in experiments I and II. Note that the effect of phytoregulators on growth promotion has been reported in forage palm genotypes under conditions of in vitro cultivation (Frota et al., 2004; Rocha et al., 2018). Ruvalcaba-Ruiz et al. (2010) reported that for the Coryphantha retusa Britton and Rose cactus, which belong to the same genotype family of the genus Nopalea, the addition of phytoregulators in the culture medium increased the organogenic potential of secondary sprouts formed from in vitro cultivation, maintaining their exogenous morphogenetic development after the induction period. However, despite finding in the literature effects associated with the use of forage palm phytoregulators under in vitro conditions, in the greenhouse, there was no gain in the development of sprouts fragments with their use.

The absence of phytoregulatory effects in all variables may be related to their low dosage in the young forage palms. It is noteworthy that the doses used in this experiment were based on studies with in vitro culture. Thus, we suggest it may be that the fragments continued to present the insufficiency of phytohormone or that the concentrations were not enough to stimulate the development of the evaluated variables. Therefore, it would be ideal to use larger doses in further experiments to test and better understand induction responses under greenhouse conditions, which are scarce in the production of young forage palm young.

Another explanation for the lack of effect of phytoregulators in experiments I and II may be associated with the fact that they were added directly to the substrate at the time of irrigation; thus, the fragments may not have completely absorbed the phytoregulators.

There are no reports cited in forage palm studies of other forms of application of phytoregulators, as there are for other species. In teak (Tectona grandis), the immersion of cuttings in a solution containing BAP relatively increased the number of sprouts (Kozgar and Shahzad, 2012; Quiala et al., 2012). Giampan et al. (2005), testing the application of BAP and $\mathrm{GA}_{3}$ in the induction of papaya sprouting by spraying, lanolin paste and trunk injection methods, showed better results with the use of spraying, although they pointed out that this method required greater consumption of BAP and GA3. The same authors pointed out that the application of phytoregulators using lanolin paste proved to be an interesting way to consume a smaller amount of these products. Even though the use of phytoregulators has been shown to have beneficial effects in previous research, its method of application on forage palms needs further study as exogenous application is linked to inherent characteristics of the species (Taiz and Zeiger, 2013).

The results observed in experiments I and II for the variables considered as indicators of young forage palm development at the considered time intervals suggest that, the use of the phytoregulators BAP in the dosages: $0.0 ; 0.5 ; 1.0$ and $1.5 \mathrm{mg}$. $\mathrm{L}^{-1}$ and Kinetin: $0.0 ; 0.25 ; 0.5$ and $0.75 \mathrm{mg}^{-1}$, combined with NAA: $1.5 \mathrm{mg}$. $\mathrm{L}^{-1}$, applied directly to the substrate, do not interfere in the development process of sprouting. Thus, the use of such phytoregulators at these concentrations is not recommended.

\section{Experiment III - Influence of stem subdivision on the production of forage palm seedlings}

Experiment III shows that the IPA Sertânia genotype produced the highest percentage of shoots at 45 DAP in the $5 \times 3 \mathrm{~cm}$ cut and obtained sprouts in all cut sizes (Figure 1).

At 60 and 75 DAP, sprouting was observed in all treatments, verifying that besides the IPA Sertânia genotype, the others also presented a potential for the formation of young plants through subdivision (Figure 1). The highest percentage of sprouting fragments of IPA Sertânia and Miúda were observed in the $5 \times 3$ and $4 \times 2 \mathrm{~cm}$ cuts and for Gigante and Orelha de Elefante in the $5 \times 3 \mathrm{~cm}$ cut. This result may be associated with factors such as water and nutrient reserve content since water and mineral salts are essential for young plants to develop satisfactorily (Cruz et al., 2016).

Silva et al. (2015), in their study of genotype establishment using the whole stem in field planting, pointed out that regarding the establishment capacity and generation of new sprouts, concerning the initial stand, IPA Sertânia was the genotype with the lowest magnitude. On the other hand, Sales et al. (2009) and Leite (2009) found that Miúda had greater difficulty in field establishing in comparison to Gigante. Thus, although the sizes of sprouting fragments were smaller in the Gigante and Orelha de Elefante at 45 
Table 1. Evaluation of different genotypes and cuts at 90 days after planting. Mass of fragments measured in grams. Average length (AL), average width (AW) and average thickness (AT) of sprouts measured in centimeters.

\begin{tabular}{|c|c|c|c|c|c|}
\hline GENOTYPES & GENUS & MASS & $\mathrm{AL}$ & AW & AT \\
\hline Gigante $5 \times 3$ & Opuntia & $20.86 \mathrm{~b}$ & $3.27 \mathrm{~b}$ & $1.96 \mathrm{a}$ & $1.23 \mathrm{a}$ \\
\hline Gigante $4 \times 2$ & Opuntia & $9.44 d$ & $2.05 c$ & $1.41 \mathrm{~b}$ & $1.13 \mathrm{a}$ \\
\hline Gigante $2 \times 2$ & Opuntia & $3.77 \mathrm{e}$ & $1.87 \mathrm{c}$ & $1.32 \mathrm{~b}$ & $1.08 \mathrm{~b}$ \\
\hline Orelha de Elefante $5 \times 3$ & Opuntia & $13.12 \mathrm{c}$ & $3.20 \mathrm{~b}$ & $1.81 \mathrm{a}$ & $1.17 \mathrm{a}$ \\
\hline Orelha de Elefante $4 \times 2$ & Opuntia & $9.09 \mathrm{~d}$ & $1.36 \mathrm{c}$ & $1.14 \mathrm{~b}$ & $1.04 \mathrm{~b}$ \\
\hline Orelha de Elefante $2 \times 2$ & Opuntia & $3.74 \mathrm{e}$ & $1.00 \mathrm{c}$ & $1.00 \mathrm{~b}$ & $1.00 \mathrm{~b}$ \\
\hline IPA Sertânia 5x3 & Nopalea & $27.12 \mathrm{a}$ & $4.61 \mathrm{a}$ & $2.07 \mathrm{a}$ & $1.23 \mathrm{a}$ \\
\hline IPA Sertânia 4×2 & Nopalea & $10.65 d$ & $3.97 \mathrm{a}$ & $1.89 \mathrm{a}$ & $1.21 \mathrm{a}$ \\
\hline IPA Sertânia 2×2 & Nopalea & $2.75 \mathrm{e}$ & $1.34 \mathrm{c}$ & $1.14 \mathrm{~b}$ & $1.03 \mathrm{~b}$ \\
\hline Miúda $5 \times 3$ & Nopalea & $12.41 \mathrm{c}$ & $4.78 \mathrm{a}$ & $2.04 \mathrm{a}$ & $1.24 \mathrm{a}$ \\
\hline Miúda 4×2 & Nopalea & $4.75 \mathrm{e}$ & $3.27 b$ & $1.71 \mathrm{a}$ & $1.17 \mathrm{a}$ \\
\hline Miúda $2 \times 2$ & Nopalea & $2.59 \mathrm{e}$ & $1.00 \mathrm{c}$ & $1.00 \mathrm{~b}$ & $1.00 \mathrm{~b}$ \\
\hline CV\% & & 24.28 & 31.42 & 19.33 & 6.33 \\
\hline
\end{tabular}

Averages followed by the same letter in the column belong to the same grouping by the Skott-Knott test at $5 \%$ significance.

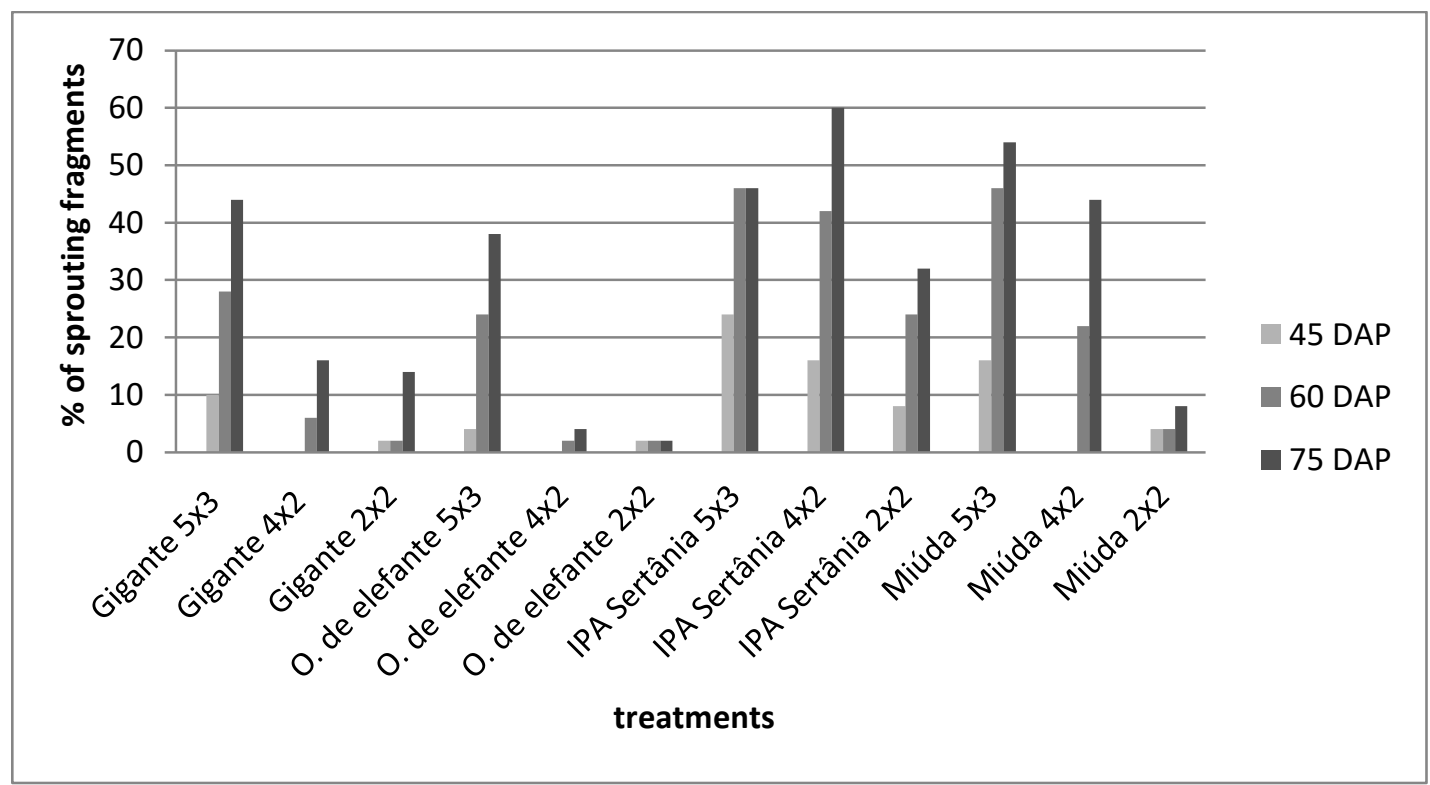

Fig 1. Evaluation of percentage of sprouted fragments at 45,60 and 75 days after planting (DAP).

DAP, there was an increase in the percentage of this feature between 60 and 75 DAP in the $5 \times 3 \mathrm{~cm}$ cut; thus, indicating this is a good fragment size to obtain young plants and that, possibly, its sprouting occurs later than IPA Sertânia and Miúda.

Significant differences were observed between treatments for the variable mass of fragments in different genotypes and cuts at 90 DAP (Table 1). The difference between the cuts is justified by the size of the fragment, and the larger the size, the greater the weight in grams. Regarding genotypes, Sales et al. (2013) report that stem area index and morphological traits vary as a function of cultivar and plant age. Leite (2009), who studied forage palm clones, showed that the stem thickness of the IPA Sertânia was significantly higher than that of the Miúda. As the cut sizes were standardized, it is suggested that the difference between genotypes in the same cut size was due to the thickness of the stem used.

Significant differences were observed for the AL, AW and AT variables of the sprouts between treatments (Table 1 ). The highest AL average of the shoots was verified in IPA Sertânia in the $5 \times 3$ and $4 \times 2 \mathrm{~cm}$ cuts and the Miúda in the $5 \times 3 \mathrm{~cm}$ cut, both genotypes of the genus Nopalea. For Opuntia genus genotypes, the best averages for the same feature were found in the Gigante and Orelha de Elefante $5 \times 3 \mathrm{~cm}$ cut. Silva et al. (2017), who investigated forage palm genotypes, reported that Gigante's stem weighs on average $1.0 \mathrm{~kg}$ and can be up to $50 \mathrm{~cm}$ long. Miúda's average weight, on the other hand, is $350 \mathrm{~g}$ whereas its average length is $25 \mathrm{~cm}$, that is, approximately half the size of Gigante stem. In this regard, it is noteworthy that despite observing the highest sprouts' AL in the IPA Sertânia and Miúda, the evaluation was performed up to 90 DAP. Therefore, it is not the case that the young plants produced from the Gigante e Orelha de Elefante genotypes have lower development than the others when fractionated, because they can grow when established in the field and reach their genetic potential, especially IPA Sertânia and the Miúda.

These results suggest that the initial development in terms of AL considering genotypes of genus Nopalea is significantly superior to plants of genus Opuntia when stem fragments are used and that the best cut for Gigante and Orelha de Elefante is $5 \times 3 \mathrm{~cm}$. 
The highest width averages were observed in the IPA Sertânia and Miúda genotypes with the $5 \times 3$ and $4 \times 2 \mathrm{~cm}$ cuts and in the case of Gigante and Orelha de Elefante with the $5 \times 3 \mathrm{~cm}$ cuts (Table 1). Silva et al. (2015), who compared the growth and productivity of three forage palm clones in the field, observed differences in length and width. In terms of the characteristics of the stem, they found that the IPA Sertânia and the Orelha de Elefante had the largest stems, whereas the Miúda had the smallest stem. Thus, despite the differences found in the literature, there is a similarity between the width in the genotypes of the same genus within the same cuts, and this may be related to morphophysiological factors of the genotypes.

Our results showed higher averages of thickness for the Gigante, IPA Sertânia and Miúda genotypes in the $5 \times 3$ and $4 \times 2 \mathrm{~cm}$ cuts and for the Orelha de Elefante in the $5 \times 3 \mathrm{~cm}$ cuts (Table 1). Silva et al. (2015) found no differences in the thickness of the Miúda, IPA Sertânia, and Orelha de Elefante stems. They report that in Miúda it appears that its stem index is lower than the index of the other species and that the Orelha de Elefante increases stem measurements until the second sprouting. It is noted that there are differences in the thickness of the sprouts between species of the same genus among the cuts, and this may be associated with the age factor since they were evaluated in the early stages of their development.

Regarding fragment size, significant differences were observed between sprouts in the different cuts for the variables AL, AW and AT at 90 DAP (Table 1).

The highest averages were observed in the $5 \times 3 \mathrm{~cm}$ cut for the Gigante, Orelha de Elefante and Miúda genotypes and the $5 \times 3$ and $4 \times 2 \mathrm{~cm}$ cuttings for the IPA Sertânia. Gava and Lopes (2012) reported that the ideal cut size is $5 \times 3 \mathrm{~cm}$ in Miúda and at least one to two buds per fragment. The IPA Sertânia, in addition to not presenting significant differences between the variables in the $5 \times 3 \mathrm{~cm}$ and $4 \times 2 \mathrm{~cm}$ cuttings had a higher percentage of plants with sprouts in the $4 \times 2 \mathrm{~cm}$ cut compared to the $5 \times 3 \mathrm{~cm}$ cut at 75 DAP (Figure 1). Thus, despite observing smaller averages in the $4 \times 2 \mathrm{~cm}$ cuts compared to the $5 \times 3 \mathrm{~cm}$ cuts of the Gigante, Orelha de Elefante and Miúda genotypes, reducing the size of the cut can be seen as beneficial, since it increases the number of young forage palms produced by the stem and reduces the final cost of production.

The lower means were observed in the $2 \times 2 \mathrm{~cm}$ cuts of all genotypes. Cavalcante et al. (2017), who examined different cut sizes in Miúda, concluded that the use of both fractions proved viable for planting; however, treatments with $1 / 6$ stem fragments presented lower initial development of their sprouts compared to $1 / 2$ stem fragments. This can be possibly related to the lower nutrient reserves content of these fragments, which hinder the development of their sprouts. In our study, this can be the reason for the smaller AL, AW and AT means that were found in the $2 \times 2 \mathrm{~cm}$ cuts. This indicates that the sprouts in this cut would not have sufficient nutrient and water reserves to provide the necessary germination conditions for the sprouts to develop optimally

In this way, before planting begins, producers should seek necessary information about the genotypes that best suit the environmental conditions and the stem cut sizes that are most suitable to increase the number of seedlings to be produced through the available propagative material.

\section{Materials and methods}

\section{Experiment location}

The study was carried out in a greenhouse and the Laboratory of Molecular Biology (LMB), at the State University of Montes Claros (UNIMONTES) Campus Janaúba -Minas Gerais. Three experiments were performed (I, II and III).

\section{Description of experiments I and II}

Experiment I was carried out from 05/04/2018 to $08 / 17 / 2018$. Tertiary stems from eight-month-old plants of Nopalea cochenillifera Salm- Dyck cv. Miúda, were obtained from a private property in Janaúba city, Minas Gerais, Brazil. Experiment II was carried out from 09/23/2018 to $01 / 05 / 2019$. Tertiary stems of the Miúda genotype, from three-year-old plants were obtained from the Agricultural Research Company of Minas Gerais (EPAMIG), located in Nova Porteirinha, Minas Gerais, Brazil.

Stems were selected considering overall plant health (free from pests and/or diseases), plant age and location of the stem. After collection, the material was sent to the LMB, where it remained for ten days to reduce stem moisture. After this period, the stems were cut using $5 \times 3 \mathrm{~cm}$ rectangular castings, with the fragments containing at least one apparent bud. Subsequently fragments were placed in the shade on paper towels for three days for healing of plant tissues caused by cuts.

The fragments were identified and weighed using a semianalytical scale. For plant formation, the fragments were inserted in plastic bags with a capacity of one liter and only $1 / 3$ of the fragment was introduced into the soil consisting of a mixture of soil and cattle manure in a ratio of $2: 1$. The young forage palms were irrigated every two days and other crop management activities were carried out according to the guidelines provided by Gava and Lopes' (2012).The treatments of experiments I and II consisted of young plants submitted to solutions with gradually increasing concentrations of phytoregulators: BAP in the dosages: 0.0 ; $0.5 ; 1.0$ and $1.5 \mathrm{mg}^{-1}$ and Kinetin: $0.0 ; 0.25 ; 0.5$ and 0.75 $\mathrm{mg}$. $\mathrm{L}^{-1}$, combined with NAA: $1.5 \mathrm{mg}$. $\mathrm{L}^{-1}$, applied directly to the substrate once a week at the time of irrigation until the 30th day after planting.

The young forage palms were taken to a greenhouse and distributed in a randomized block design (RBD), in a factorial scheme with an additional plot: $4 \times 4+1$ (four doses of BAP with four of Kinetin and an additional control with no dosage of BAP and Kinetin), totaling 17 treatments. Four blocks and five plants per plot were used, totaling 340 young plants to be evaluated in each experiment. The variables examined in this experiment were: average length ( $A L)$, average width (AW) and average thickness (AT) of sprouts measured using a tape measure and evaluated at the $45^{\text {th }}, 60^{\text {th }}, 75^{\text {th }}$ and $90^{\text {th }}$ day after planting (DAP).

\section{Description of experiment III}

Experiment III was carried out from 10/13/2018 to $1 / 26 / 2019$.Tertiary stems of four different forage palm 
genotypes were used: Gigante (Opuntia ficus-indica Mill), Orelha de elefante (Opuntia sp.), IPA Sertânia (Nopalea sp.) and Miúda (Nopalea cochenillifera Salm- Dyck). These stems were obtained from the company EPAMIG Norte located in Nova Porteirinha, Mina Gerais.

After the period of reducing stem moisture, they were cut using aluminum castings of different sizes: $5 \times 3 \mathrm{~cm}, 4 \times 2 \mathrm{~cm}$, and $2 \times 2 \mathrm{~cm}$, with the fragments containing at least one apparent bud. Subsequently, for three days, the fragments were placed on paper towels in the shade for plant healing. When planting the fragments, they were identified and weighed using a semi-analytical scale. To allow plant growth , the fragments were inserted in plastic bags with a capacity of one liter, being $1 / 3$ of the fragment introduced in the soil, consisting of a mixture of soil and cattle manure in a ratio of 2: 1 . The young plants were irrigated every two days and other crop management activities were carried out according to Gava and Lopes' (2012) recommendations.

The seedlings were distributed in the greenhouse in completely randomized blocks, with the following 12 treatments: T1-Gigante $5 \times 3 \mathrm{~cm}$; T2-Gigante $4 \times 2 \mathrm{~cm}$; T3Gigante $2 \times 2 \mathrm{~cm}$; T4-O. de Elefante $5 \times 3 \mathrm{~cm}$; T5-O. de Elefante $4 \times 2 \mathrm{~cm}$; T6-O. de Elefante $2 \times 2 \mathrm{~cm}$; T7-IPA Sertânia $5 \times 3 \mathrm{~cm}$; T8-IPA Sertânia $4 \times 2 \mathrm{~cm}$; T9-IPA Sertânia $2 \times 2 \mathrm{~cm}$; T10-Miúda $5 \times 3 \mathrm{~cm}$; T11-Miúda $4 \times 2 \mathrm{~cm}$ and T12-Miúda $2 \times 2 \mathrm{~cm}$. Five blocks and five plants per plot were used, totaling 300 young plants, which were evaluated in the study. The variables considered in this experiment included: (i) sprouting, evaluated in terms of percentage (\%) at $45^{\text {th }}, 60^{\text {th }}$, and $75^{\text {th }}$ DAP; and (ii)average length (AL), average width (AW) and average thickness (AT) of the shoot, evaluated at the $90^{\text {th }}$ DAP (similar to the procedure in experiments I and II).

\section{Statistical analysis}

The assumptions for variance analysis, as the normal distribution of data and homogeneity of variances by the Lilliefors $(p<0.05)$ and Hartley $(p<0.05)$ tests, respectively, were verified (ANOVA) for the variables analyzed in these experiments. Except for the presence of sprouting that did not present those assumptions, descriptive statistics based on average values were used. The variables AL, AW and AT were transformed using the function $Y=V(x+1)$ due to the absence of normality. Once the assumptions were met, the variables were submitted to the $\mathrm{F}$ test with a $5 \%$ probability of error. When significant, the means were compared by the Scott and Knott test $(p<0.05)$. Statistical analyses were conducted using the Genes software (Cruz, 2016).

\section{Conclusions}

The phytoregulators BAP in the dosages: $0.0 ; 0.5 ; 1.0$ and 1.5

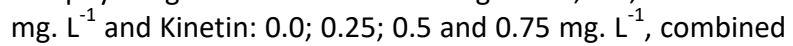
with NAA: $1.5 \mathrm{mg}$. $\mathrm{L}^{-1}$, applied directly to the substrate, do not interfere in the development process of sprouting in the forage palm fragments of the Miúda genotype.

For the Gigante, Orelha de Elefante and Miúda genotypes, the recommended fractional stem size is $5 \times 3 \mathrm{~cm}$, and for the IPA Sertânia, the size recommended is $4 \times 2 \mathrm{~cm}$.

\section{Acknowledgements}

The authors are very thankful to the following organizations: CAPES for the financial support provided "financial code 001", UNIMONTES for the scientific development opportunity, and EPAMIG for the donation of biological material.

\section{References}

Calaes JG, Londe LCN, Rocha SS, Maranhão CMA, Teixeira BA, Junior MM, Nietsche, S (2017). In vitro cultivation of forage palm cv. giant with different concentrations of 1naphthaleneacetic acid under artificial and natural light. Journal of advances in biology \& biotechnology. 13: 1-7.

Cavalcante JMM (2017) Desenvolvimento inicial de brotações com uso de $1 / 2$ e $1 / 6$ do cladódio na propagação da palma forrageira Nopalea cochenillifera var. miúda. PUBVET: Med Vet e Zootec. 11 (8): 819-824.

Cruz CD (2016) Genes Software-extended and integrated with the R, Matlab and Selegen. Acta Scientiarum. Agronomy. 38(4): 547-552.

Cruz FRS, Andrade LA, Feitosa RC (2016) Produção de mudas de umbuzeiro (Spondias tuberosa Arruda Câmara) em diferentes substratos e tamanho de recipientes. Ciência Florestal. 26(1): 69-80.

Frota HM, Carneiro MSS, Zárete RML, Campos FAP, Peixoto MJA (2004) Proliferação e enraizamento in vitro de brotos de palma forrageira - Opuntia ficus-indica (L.) MILL. Acta Scientiarum. 26(2): 235-238.

Gava CAT, Lopes EB (2012) Produção de mudas de palma forrageira utilizando fragmentos de cladódios. Petrolina: Embrapa Semiárido. Disponível em: https://ainfo.cnptia.embrapa.br/digital/bitstream/item/63 884/1/INT101.pdf. Acesso em: 15 maio 2019.

Giampan JS, Cerqueira TS, Jacomino AP, Rezende JAM, Sasaki FF (2005) Indução de brotos laterais de mamoeiro (Carica papaya L.). Rev Bras de Fruticultura. 27(1): 185187.

Kozgar MI, Shahzad A (2012) An improved protocol for micropropagation of teak tree (Tectona grandis L.). Rendiconti Lincei. 23: 195-202.

Krikorian AD (1991) Medios de cultivo: generalidades, composición y preparación. In: Roca WR, Mroginski LA (ed). Cultivo de tejidos em la agricultura: fundamentos y aplicaciones. Cali, Colombia: Centro Internacional de Agricultura Tropical. p. 41-78.

Leite MLMV (2009) Avaliação de clones de palma forrageira submetidos a adubações e sistematização de informações em propriedades do Semi-árido paraibano. Tese (Doutorado em Zootec) - Universidade Federal da Paraíba, Areia, 2009.

Lima GFC, Rego MMT, Dantas FDG, Lôbo RNB, Silva JGM, Aguiar EM. (2016). Morphological characteristics and forage productivity of irrigated cactus pear under different cutting intensities. Revista Caatinga, 29(2), 481-488.

Pal SL (2019) Role of plant growth regulators in floriculture: An overview. Journal of Pharmacognosy and Phytochemistry 8 (3): 789-796.

Pereira Júnior JS (2007) Nova delimitação do Semiárido brasileiro. Biblioteca Digital da Câmara dos Deputados. Centro de Documentação e Informação. 32p.

Pimentel-Gomes F (1987) Curso de estatística experimental. 12. ed. São Paulo, Nobel, 466p.

Quiala E, Cañal MJ, Meijón M, Rodriguez R, Chávez $M$, Valledor L, Feria M, Barbón R (2012) Morphological and physiological responses of proliferating shoots of teak to temporary immersion and BA treatments. Plant Cell, Tissue and Organ Culture. 109(2): 223-234. 
Rademacher W (2015). Plant Growth Regulators: Backgrounds and Uses in Plant Production. Journal of Plant Growth Regulation. (34): 845-872.

Rocha SS, Londe LCN, Calaes JG, Pereira JCG, Vieira VS, Mota MCB, Farias RAN (2018) Effect of lighting spectrum and naphthaleneacetic acid (NAA) on the in vitro development of cactus pear (Opuntia ficus-indica (L.) Mill). Australian Journal of Crop Science. 12(12): 1837-1843.

Ruvalcaba-Ruiz D, Rojas-Bravo D, Valencia-Botin AJ (2010) Propagación in vitro de Coryphantha retusa (Britton \& Rose) um cactus endémico y amenazado. Tropical and Subtropical Agroecosystems. 12(1): 139-143.

Sales AT, Andrade AP, Leite ML, Silva DS, Viana BL, Santos EG (2009) Mortality index of forage cactus in the semiarid of Paraiba State-Brazil. Acta Horticulturae. 811: 401-406.
Sales AT, Leite MLMV, Alves AQ, Ramos JDF, Nascimento JD (2013) Crescimento vegetativo de palma forrageira em diferentes densidades de plantio no Curimatú Paraibano. Tecnologia \& Ciência Agropecuária, João Pessoa. 7(1): 1924.

Silva JA, Donato SL, Donato PER, Rodrigues MGV (2017) Cultivares e manejo de palma forrageira. Informe Agropecuário. 38(296): 34-35.

Silva TGF, Primo JTA, Morais JEF, Diniz WJS, Souza CAA, Silva MC (2015) Crescimento e produtividade de clones de palma forrageira no semiárido e relações com variáveis meteorológicas. Revista Caatinga. 28(2): 10-18.

Taiz L, Zeiger E (2014) Plant physiology. 6rd.edn. Sunderland: Sinauer Associates. 